\title{
The breeding season of C oryphoblennius galerita in Portuguese waters
}

\author{
V. C. A lmada, H. Carreiro, C. F aria and E. J. G onçalves \\ U nidade de Investigação em E co-E tologia, Instituto Superior de P sicologia A plicada, \\ $\mathrm{R}$ ua J ardim do T abaco, 44, P-1100 Lisbon, Portugal
}

(Received 30 J uly 1994, A ccepted 31 M arch 1995)

\begin{abstract}
Coryphoblennius galerita at three sites on the Portuguese coast breeds from F ebruary/M arch to September/O ctober.

(C) 1996 The Fisheries Society of the British Isles
\end{abstract}

K ey words: Blenniidae; breeding season; latitudinal variation; littoral fish.

Coryphoblennius galerita (L.) is a widely distributed, rocky intertidal fish (Zander, 1986). It spawns demersal eggs that are cared for by the male until hatching (M ilton, 1983). The breeding season of this species varies substantially with latitude: late J une to early A ugust on the south coast of the U .K . (M ilton, 1983); A pril to A ugust on the southwest coast of Ireland (Fives, 1980a); and A pril to September in Brittany, France (Fives, 1970). Observations of nests indicated that breeding lasts from $M$ arch to September along the coast of mainland Portugal (A Imada et al., 1983), but there are no reliable quantitative data for this part of the species range. In this paper we present data on the breeding season of $\mathrm{C}$. galerita in Portuguese waters, and compare the results with the information available for other parts of the species range.

M ost data were collected near the mouth of the R. Tagus ( $\mathrm{L}$ isbon) $\left(38^{\circ} 41^{\prime} \mathrm{N}, 9^{\circ} 22^{\prime} \mathrm{W}\right.$ ), between J une 1991 and N ovember 1994. The area surveyed comprises about $1 \mathrm{~km}$ of rocky shore. Additional data were collected between F ebruary and September 1993 at Cabo R aso ( $\left.38^{\circ} 42^{\prime} \mathrm{N}, 9^{\circ} 29^{\prime} \mathrm{W}\right)$ and at A rrábida coast ( $\left.38^{\circ} 28^{\prime} \mathrm{N}, 8^{\circ} 59^{\prime} \mathrm{W}\right)$.

$\mathrm{N}$ ests were located at low tide by inspecting small holes and crevices on exposed intertidal rocks. Only holes that contained, or had contained eggs, were classified as nests. The location of each nest was mapped for subsequent visits. All known nests were visited at approximately monthly intervals, and the presence of fish and/or eggs was recorded. F rom J une 1993, 21 nests were inspected regularly, allowing a standardization of the observational effort. Since the eggs and nest are guarded by males (F ives, 1980b; A Imada et al., 1983), we assumed that males found together with eggs were breeding individuals.

$M$ ales of $C$. galerita were found guarding eggs in small holes or crevices in rocks at different levels in the intertidal zone. $V$ isual observation of the nests indicate that they usually contained eggs in different stages of development, showing that males guard eggs spawned at different times. R egular monthly inspections of all known nests recorded eggs up to September in 1991, from M arch to September in 1992 and 1994, and from $\mathrm{M}$ arch to October in 1993 (Fig. 1).

Females with a red genital papilla, which in the related species Salaria pavo (R isso) indicates spawning (Patzner et al., 1986), were found in tide pools only between $\mathrm{M}$ arch and September.

Six nests were found with eggs on 26/27 F ebruary 1993 at Cabo Raso. Thus, we conclude that breeding starts at the end of $\mathrm{F}$ ebruary/beginning of $\mathrm{M}$ arch and ends at the end of September/beginning of O ctober along the Portuguese coast.

Few fish were found in the holes used as nests outside the breeding season. There was a significant positive correlation between the number of holes occupied by fish and the 


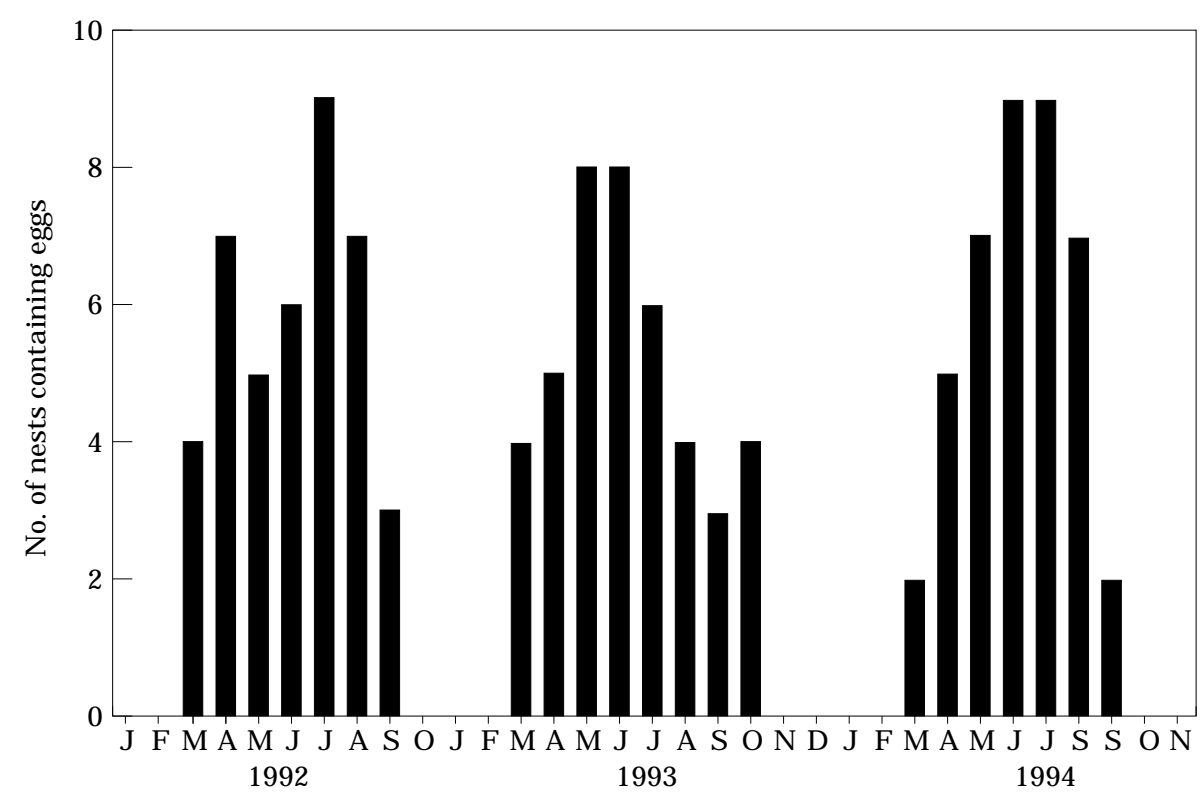

F IG. 1. N umber of nests containing eggs during the years 1992, 1993 and 1994. The exact date for each month and the number of nests checked at each visit (n) was as follows: 1992: $22 \mathrm{~J}$ an. (7); $21 \mathrm{Feb}$. (7); $19 \mathrm{M}$ ar. (10); $17 \mathrm{~A} \mathrm{pr.} \mathrm{(14);} 16 \mathrm{M}$ ay (14); 15 J un. (15); $15 \mathrm{~J}$ ul. (18); 4 A ug. (18); 12 Sep. (18); 10 Oct. (18). 1993: $21 \mathrm{~J}$ an. (20); $9 \mathrm{~F} \mathrm{eb.} \mathrm{(20);} 26 \mathrm{M}$ ar. (20); $12 \mathrm{~A} \mathrm{pr.} \mathrm{(20);} 3 \mathrm{M}$ ay (20); $2 \mathrm{~J}$ un. (21); $4 \mathrm{Jul}$. (21); 1 A ug. (21); 4 Sep. (21); 2 Oct. (21); 28 N ov. (21); 30 D ec. (21). 1994: $26 \mathrm{~J}$ an. (21); 24 F eb. (21); $15 \mathrm{M}$ ar. (21); 24 A pr. (21); $24 \mathrm{M}$ ay (21); 22 J un. (21); 21 J ul. (21); 4 Sep. (21); 20 Sep. (21); 3 Oct. (21); 17 N ov. (21).

number of holes containing eggs (Spearman Rank Correlation: $r_{s}=0.801, P<0.001$, number of monthly visits $=23$ ). These results suggest strongly that territorial defence of the nests is restricted to the breeding season, a situation that contrasts with the pattern of permanent territoriality of some tropical blenniids (F ishelson, 1975; L osey, 1976; N ursall, 1977; Phillips, 1977).

In this population most nests were used for periods that were much shorter than the breeding season as a whole. The duration of occupancy of both eggs and males in each nest varied (eggs: mean $=1.88$ months, s.D. $=1.36$, range $1-6$ months; males: mean $=2.14$ months, s.D. $=1 \cdot 47$, range $1-7$ months) (data for 20 nests followed during 1993). Occupancy in six nests was intermittent, and in one nest a male was present even in months when there were no eggs in the nest.

The breeding season of $C$. galerita in different locations increases in duration from cooler to warmer waters. In Portugal, where temperatures are higher, breeding not only starts earlier (F ebruary/M arch) but it also ends later (September/O ctober) than in the northern part of the species range. This difference is not due to methodological differences. Indeed, while for instance M ilton (1983) based his results on the inspection of fish, our data are based on the occurrence of eggs in the nests. This method is likely to underestimate the onset and the end of the breeding season, when very few nests contained eggs. This means that, if anything, the breeding season in Portugal may be somewhat longer than reported here.

A $n$ increasing duration of the breeding season with decreasing latitude was found by several authors [e.g. Dahlberg \& Conyers (1973) for fish of the A tlantic coast of the U nited States and M iller (1961) for west European species]. Conover (1992) argued that at high latitudes natural selection would favour fish that start to breed as soon as environmental conditions are favourable in order to maximize the size attained by juveniles when they reach their first winter. The onset and the end of the breeding season 
of several western A tlantic species tend to occur at similar temperatures at different latitudes, leading to a marked reduction in the duration of the breeding season at higher latitudes (Conover, 1992). M iller (1961) also argued that latitudinal variation should be more pronounced for the beginning of the breeding season, since larvae that hatch late in the year should be subjected to unfavourable conditions in terms of reduced food availability and low temperature. This pattern was confirmed in C. galerita. Indeed, latitudinal variation is more pronounced at the onset than at the end of the breeding season.

These results stress the need for a more comprehensive comparative work on the breeding season of inshore fish along their geographical ranges.

Part of this study was supported by J unta $\mathrm{N}$ acional de Investigação Científica e Tecnológica as part of the project PBIC/1313/M AR/92. C.F. and E.G. were also supported by grants from J ICT, respectively (C/BIC/797/93) and (BD/872/90-IG ). W e thank M iguel Henriques, Elsa R odrigues and D avid G onçalves for help in the field work; Clara A morim for review of the English; and two anonymous referees for suggestions.

\section{R eferences}

A Imada, V., D ores, J., Pinheiro, A ., Pinheiro, M . \& Santos, R . S. (1983). Contribuição para o estudo do comportamento de Coryphoblennius galerita (L.) (Pisces: Blenniidae). M emórias do M useu do M ar-série Z oológica 2, 1-166.

Conover, D. O. (1992). Seasonality and the scheduling of life history at different latitudes. J ournal of Fish Biology 41 (suppl. B), 161-178.

Dahlberg, M. D. \& Conyers, J. C. (1973). An ecological study of Gobiosoma bosci and Gobiosoma ginsburgi (Pisces: G obiidae) on the G eorgia coast. Fisheries Bulletin U.S. 71, 279-287.

Fishelson, L. (1975). Observations on the behaviour of the fish M eiacanthus nigrolineatus Smith-Vaniz (Blenniidae) in nature (R ed Sea) and in captivity. A ustralian J ournal of M arine and Freshwater Research 26, 329-341.

Fives, J. M. (1970). Investigations of the plankton of the west coast of Ireland. IV. Larval and post-larval stages of fishes taken from the plankton of the west coast in surveys during the years 1958-1966. P roceedings of the R oyal I rish A cademy B 70, 15-93.

Fives, J. M . (1980a). Littoral and benthic investigations on the west coast of I reland. XI. The biology of M ontagu's blenny, Coryphoblennius galerita L. (Pisces), on the Connemara coast. P roceedings of the R oyal I rish Academy B 80, 63-79.

Fives, J. M. (1980b). An account of the eggs and developmental stages of M ontagu's blenny, Coryphoblennius galerita (L.), with notes on the reproductive behaviour of the adults. J ournal of the M arine Biological Association of the U nited Kingdom 60, 749-757.

L osey, G. S. (1976). The significance of coloration in fishes of the genus $\mathrm{H}$ ypsoblennius, G ill. Bulletin of the Southern California A cademy of Sciences 75, 183-198.

M iller, P. J. (1961). A ge, growth and reproduction of the rock goby, Gobius paganellus L., in the Isle of $M$ an. J ournal of the $M$ arine Biological A ssociation of the U nited Kingdom 41, 737-769.

$M$ ilton, P. (1983). Biology of littoral blenniid fishes on the coast of south-west England. J ournal of the $M$ arine Biological A ssociation of the U nited Kingdom 63, 223-237.

N ursall, J. R. (1977). Territoriality in redlip blennies (O phioblennius atlanticus-Pisces: Blenniidae). J ournal of Z oology 182, 205-223.

Patzner, R. A ., Seiwald, M ., A dlgasser, M \& \& K aurin, G. (1986). The reproduction of B lennius pavo. V. $R$ eproductive behaviour in natural environment. Z oologischer A nzeiger 216, 338-350.

Phillips, R. R. (1977). Behavioral field study of the H awaiian rockskipper, I stiblennius zebra (Teleostei, Blenniidae). I. Ethogram. Z eitschrift für Tierpsychologie 43, 1-22.

Zander, C. D. (1986). Blenniidae. In Fishes of the North-Eastern Atlantic and the Mediterranean (Whitehead, P. J. P., Bauchot, M.-L., Hureau, J.-C., Nielsen, J.\& Tortonese, E., eds), pp. 1096-1112. Paris: UNESCO. 